Vol 12, Issue 2, 2019

\title{
DEVELOPMENT AND CHARACTERIZATION OF BIOCOMPATIBLE POLYHYDROXY BUTYRATE IMPREGNATED WITH HERBAL PLANTS AGAINST WOUND HEALING ACTIVITY ON IN VIVO ANIMAL MODEL
}

\author{
RAM NARENDRAN R ${ }^{1 *}$, MALEEKA BEGUM SF ${ }^{2}$, RUBAVATHI ${ }^{3}$ \\ ${ }^{1}$ Research and Development Centre, Bharathiar University, Coimbatore, Tamil Nadu, India. ${ }^{2}$ Department of Biotechnology, Sri \\ Ramakrishna College of Arts and Science, Coimbatore, Tamil Nadu, India. ${ }^{3}$ Department of Biotechnology, K.S.R. College of Technology, \\ Tiruchengode, Tamil Nadu, India. Email: ramnarendrannkg@gmail.com
}

Received: 18 August 2018, Revised and Accepted: 12 October 2018

ABSTRACT

Objective: The current study is to evaluate the antimicrobial, antioxidant, anti-inflammatory, and in vitro cytotoxicity activities of polyhydroxybutyrate (PHB) and to develop the herbal impregnated PHB cast film for wound healing activities using Albino Wistar rat model.

Methods: PHB produced by Azotobacter chroococcum A3 strain was synthesized and characterized (previous study). The PHB was subjected to various biocompatibility studies such as antimicrobial, antioxidant, and anti-inflammatory studies. The PHB was also subjected to cytotoxicity study by (3-[4,5-dimethylthiazol-2-yl]-2,5 diphenyl tetrazolium bromide) assay. PHB films were made using different combinations of plant and algal blends (herbal blends). The herbal blends of PHB films were evaluated for in vivo wound healing activity using Albino Wistar rats.

Results: The turmeric impregnated PHB showed the highest result for antimicrobial with $27.25 \pm 0.23 \mathrm{~mm}$ against skin pathogens and antioxidant activity with the highest percentage of inhibition of $76 \%$. The result predicts that PHB will not let to any toxic substances rather it acts as a chemoprotective agent followed by the inhibitory concentration value was found to be $1.56 \mu \mathrm{g} / \mathrm{ml}$ for $100 \mu \mathrm{g}$. The in vivo study showed better wound healing activity for PHB blended with $2 \%$ turmeric leaf and rhizome cast film. Whereas the wound healing activity of control and crude PHB was $90.4 \pm 0.4$ and $91.3 \pm 0.56$ respectively.

Conclusion: The results from the present study showed that PHB can act as a good candidate for drug carrier and it is biocompatible in living cells.

Keywords: Polyhydroxybutyrate, Azotobacter chroococcum, Biocompatibility, (3-[4,5-Dimethylthiazol-2-yl]-2,5 diphenyl tetrazolium bromide) assay, Herbal blends, In vivo study.

(c) 2019 The Authors. Published by Innovare Academic Sciences Pvt Ltd. This is an open access article under the CC BY license (http://creativecommons. org/licenses/by/4. 0/) DOI: http://dx.doi.org/10.22159/ajpcr.2019.v12i2.29179

\section{INTRODUCTION}

Polyhydroxybutyrate (PHB) is bacterial polymers formed naturally as storage polymers by many microorganisms under unbalanced growth conditions [1]. These are widespread in prokaryotes and enhance the survival during the times of starvation [2]. PHB has widespread attention, that it can be used in a wide range of agricultural, industrial, and various medical applications due to its biodegradability and biocompatibility. In medical field and tissue engineering, PHBs were used to develop devices including sutures, repair devices, repair patches, sling, cardiovascular patches, orthopedic pins, adhesion barriers, guided tissue repair, regeneration devices, articular cartilage repair devices, nerve guides, tendon repair devices, bone marrow scaffolds, and wound dressings [3]. PHB produced by Bacillus mycoides DFC 1 was incorporated with vanillin and films were produced and subjected to antimicrobial activity against foodborne pathogens and spoilage bacteria and fungi. The minimum concentration of vanillin incorporated PHB films was $\geq 80 \mu \mathrm{g} / \mathrm{g}$ PHB for bacteria and $\geq 50 \mu \mathrm{g} / \mathrm{g}$ PHB for fungi [4]. PCL-PHB blend microspheres were prepared by water/oil/water double emulsion solvent evaporation method and were encapsulated with tamoxifen (TAM), an anticancer drug and analyzed for the in vitro drug release study [5]. The study revealed that the TAM was released in a controlled manner for $>12 \mathrm{~h}$ by influencing the composition of PHB, pH, and drug loaded. PHB produced by Azotobacter chroococcum 23 showed promising results against two Gram-positive (Bacillus cereus and Staphylococcus aureus) and two Gramnegative (Escherichia coli and Pseudomonas aeruginosa) bacterial strains. The antimicrobial materials are PHB and PHB/paper systems including Silbiol or benzoic acid [6]. The PHB was also used in packaging materials in which the antimicrobial activity of PHB/chitosan films and the quality of white bread packaged with the films was investigated by Kim [7]. In his study, PHB (L) film showed high antimicrobial activity against Fusarium solani KCTC 6636 and Penicillium citreonigrum KCTC 6927. The colonyforming units of microorganisms for white bread packaged with PHB (M), PHB (L), and chitosan film were low during storage. The PHBs were blend with various other compounds for a good tenture, support, and degradability. The majorly used substrate was PEG and valeric acid. Many other blends were also used. These blends show good biocompatibility, and hence, these were used in many animal models. PHBs are suitable for scaffolding materials in tissue engineering and are proved by various studies. Shishatskaya and Volova [8] proved that NIH 3T3 fibroblast cells adhere and proliferate on PHA membranes. Mesenchymal stem cells adhere and proliferate on several PHA substrates, with a terpolymer $\mathrm{P}$ (HB-co-hydroxyvalerate-cohydroxyhexanoate) P (HB-co-HV) [9]. PHB matrices have also been tested for hemocompatibility with mammalian blood incubated with polymer films. It was identified that PHB or P (HBco-HV), in contact with blood did not interfere in platelet responses, nor polymer activates the complement system [10,11]. The present study involves the biocompatibility study of PHB produced by A. chroococcum A3 strain. The various biocompatibility studies include antimicrobial, antioxidant, anti-inflammatory, and antiadherent of bacterial colonies. The cytotoxicity was studied using (3-[4,5-dimethylthiazol-2-yl]-2,5 diphenyl tetrazolium bromide) (MTT) assay. Various PHB films with different herbal blends were made and were subjected to in vivo wound healing activity using Albino Wistar rats.

\section{METHODS}

\section{Biocompatibility study}

The biocompatibility study was done to examine whether the produced PHB was able to compate with the living cells without producing any 
harmful effect. The compatibility study involves, anti-inflammatory study and MTT assay using HEK293 fibroblast cell lines.

\section{Anti-inflammatory study}

From the previous investigation, PHB from A. chroococcum A3, A4, and Bacillus megaterium was used for the anti-inflammatory study. A $0.5 \mathrm{ml}$ of the PHB extracted from A. chroococcum A3, A4, and B. megaterium was mixed with and $0.5 \mathrm{ml}$ of $1 \%$ of egg albumin solution (phosphate buffered saline). The standard drug diclofenac sodium $(5 \mathrm{mg} / \mathrm{ml})$ was mixed in $1.5 \mathrm{ml}$ of phosphate buffered saline (pH6.4) and $0.5 \mathrm{ml}$ of egg albumin solution (1\%). The mixtures were incubated at $37^{\circ} \mathrm{C}$ for $20 \mathrm{~min}$ and then denaturated at $90^{\circ} \mathrm{C}$ in a water bath for $2 \mathrm{~min}$. The solution was measured spectrophotometrically at $660 \mathrm{~nm}$. The inhibition of the PHB was calculated using the formula:

$$
\text { Inhibition }(\%)=\left(A_{t}-A_{c}\right) / A_{c} \times 100
$$

Where, $A_{c}=$ Absorbance of control, $A_{t}=$ Absorbance of test sample.

\section{MTT assay [12]}

To evaluate the cytotoxicity of PHB, cell viability study was carried out with the conventional MTT - reduction assay with small modifications. HEK 293 fibroblast cells $\left(1 \times 10^{5} /\right.$ well $)$ were plated in 96-well plates (Costar Corning, Rochester, NY), and the cells were allowed to attach and were grown for $48 \mathrm{~h}$, in $200 \mathrm{ml}$ of Dulbecco's modified eagle medium with $10 \%$ foetal bovine serum. After $48 \mathrm{~h}$ incubation, the cell ranges the confluence. Then, cells were incubated with different concentrations of the PHB, namely 6.25, 12.5, 25, 50, and $100 \mathrm{mg} / \mathrm{ml}$ (minimum 3 wells were seeded with each concentration). Equal concentrations of ascorbic acid were used as positive control, and the cells were incubated for $48 \mathrm{~h}$ followed by addition of MTT $(10 \mathrm{ml}$ and $5 \mathrm{mg} / \mathrm{ml})$ and the cells were incubated at $37^{\circ} \mathrm{C}$ for another $4 \mathrm{~h}$. The viable cell was determined by the absorbance at $570 \mathrm{~nm}$. Inhibitory concentration $\left(\mathrm{IC}_{50)}\right.$ was determined graphically, and blanks were maintained. The effect of the samples on the proliferation of HEK 293 fibroblast cell lines was expressed as the percentage cell viability, using the following formula:

$\%$ cell viability=A570 of treated cells/A570 of control cells $\times 100 \%$.

\section{PHB-plant and algal cast film preparation}

Plant and algal products were powdered, mixed with water and glycerol in the composition 50:15:35 (w/v/v), respectively. The contents were mixed for 15-30 min in constant stirring speed to obtain a clumsy paste. The paste was transformed into thermoelastic by heating at $100^{\circ} \mathrm{C}$ in a water bath with continuous stirring for $15 \mathrm{~min}$. The thermostable herbal product was mixed with PHB in the ratios 58:52 (w/w) and 100:20 (w/w), and solvent cast films were obtained. The plants turmeric and sago and macroalgae Amphiroa fragilissima and Padina tetrastromatica were used for the formulations. The formulations were used for antimicrobial and antioxidant studies and cast films of PHB with turmeric leaf, turmeric rhizome $1 \%$ and turmeric leaf, turmeric rhizome $2 \%$, respectively, were used for wound healing activity study.

\section{Antimicrobial activities of biofilm with PHB against skin pathogens} The antimicrobial activity was performed by Kirby et al. [13] method. Using sterile swabs, fresh overnight cultures of various skin pathogen bacterial cultures were swabbed onto Mueller-Hinton agar plates. Using different plant and algal formulation of PHB were impregnated as discs on to the plates. The plates were then incubated at $37^{\circ} \mathrm{C}$ for $12-24 \mathrm{~h}$. The plates were observed for the zones of inhibition and results were recorded.

2,2-Diphenyl-2-picrylhydrazyl (DPPH) radical scavenging activity of various herbs impregnated with PHB

The antioxidant property of the different herbal formulations has been determined by DPPH radical scavenging assay. This is done using the stable free radical DPPH, which get reduced in the presence of an antioxidant compound that, in turn, decreases absorbance ability of DPPH at $517 \mathrm{~nm}$. The higher radical-scavenging activity of the herbal formulations was indicated by a lower absorbance at $517 \mathrm{~nm}$. The scavenging activity of formulation and standard, ascorbic acid on DPPH was expressed as an IC ${ }_{50}$ value. The $\mathrm{IC}_{50}$ value was noted. The percentage of radical scavenging activity was calculated using the formula:

$$
\% \text { inhibition=[(AC-AT }) / A C] \times 100
$$

Where AC and AT are the absorbance of blank and extract, respectively [14].

\section{Ferric reducing antioxidant power (FRAP) assay}

The FRAP assay was estimated according to the procedure stated in Mahendran et al. [14]. The equivalent concentration of antioxidant giving an absorbance increase in the FRAP assay is equivalent to the theoretical absorbance value of $1 \mathrm{~mol} / \mathrm{L}$ concentration of Fe (II) solution. The absorbance was measured at $700 \mathrm{~nm}$ with a UV-visible spectrophotometer.

\section{Hydrogen peroxide assay}

$\mathrm{H}_{2} \mathrm{O}_{2}$ scavenging activity by SNP's was used to determine antioxidant ability. $\mathrm{H}_{2} \mathrm{O}_{2}$ solution of $(0.2 \mathrm{M})$ was prepared in phosphate buffer (pH 7.4). $1 \mathrm{ml}$ of different concentrations $(20,40,60,80$, and $100 \mathrm{mg} / \mathrm{ml})$ was added to $0.6 \mathrm{ml}$ solution of $40 \mathrm{mM}$ hydrogen peroxide solution. The absorbance of the mixture was measured at $230 \mathrm{~nm}$ using UV-visible spectrophotometer against a blank solution containing phosphate buffer saline without $\mathrm{H}_{2} \mathrm{O}_{2}$. The ascorbic acid was used as positive control. $\mathrm{IC}_{50}$ value was determined by linear regression analysis. The percentage of $\mathrm{H}_{2} \mathrm{O}_{2}$ scavenging was calculated by the following formula:

$\%$ inhibition=[1-(Absorbance of extract/Absorbance of control) $] \times 100$

\section{Mechanical property}

The different herbal blends with PHB films were analyzed for the mechanical property, the tensile strength (TS), percentage elongation at break (\% E), and elastic modulus (EM) were measured according to standard method ASTM D882, using Instron 3365 universal testing machine with a load cell of $30 \mathrm{~kg}$. Films were cut in the form of strips with a dimension of $10 \times 70 \mathrm{~mm}$, strips were clamped between two tensile grips, and the initial gauge length was set at $30 \mathrm{~mm}$. The tests took place at room temperature without humidity control. Initial grip separation and crosshead speed were performed at $2 \mathrm{~mm} / \mathrm{min}$. TS and $\mathrm{EM}$ were expressed in $\mathrm{N}$ and $\mathrm{MPa}$, and \% $\mathrm{E}$ in percentage (\%). 10 measurements for each film sample were used for test and values were determined by the mean.

\section{Wound healing activity of turmeric impregnated with PHB on in vivo model}

Healthy inbred male Wistar albino rats weighing (165-180 g) were obtained from the experimental animal house, KSR College of Technology, Tiruchengode, Tamil Nadu, India, and used for this study. All rats were divided randomly into six groups ( $\mathrm{n}=6$ in each). Animal houses were maintained in standard environmental conditions of temperature $\left(22 \pm 3^{\circ} \mathrm{C}\right)$, humidity $(60 \pm 5 \%)$, and a $12 \mathrm{~h}$ light/dark cycle. The animals were fed on a standard pellet diet and fresh tap water. All the experimental procedures and protocols used in this study were in accordance with the guidelines of the CPCSEA, New Delhi (1826/PO/EReBi/S/15/ CPCSEA, dated: 14.09.2015), with the approval of Institutional Animal Ethics Committee (IAEC) (KSRCT/BT/IAEC/2018/27), of KSR College of Technology, Tiruchengode, Tamil Nadu, India.

\section{Induction of incision wound model}

The experimental animals were grouped into six containing six animals each and treated as follows:

- Group I: Control (untreated),

- Group II: PHB biofilm,

- Group III: Turmeric leaf $1 \%$ with PHB based biofilm,

- Group IV: Turmeric rhizome $1 \%$ with PHB based biofilm,

- Group V: Turmeric leaf $2 \%$ combined with PHB based biofilm,

- Group VI: Turmeric rhizome $2 \%$ combined with PHB based biofilm. 
All animals of experimental groups were anesthetized using a low dosage of phenobarbital IP injection in an aseptic condition and observed throughout the study. A circular wound of $2 \mathrm{~cm}$ length incision was made through the skin at a distance about $2 \mathrm{~cm}$ from the middle on the right side. All the test biofilms of $3 \times 3 \mathrm{~cm}$ were plastered on the wounded area twice daily. Percentage of wound contraction was calculated as:

Percentage of wound size $=$ Wound area on day $\mathrm{X} /$ Wound area on day zero $\times 100$. Percentage of wound healing $=100-$ Percentage of wound size. Percentage of wound contraction was calculated on $2^{\text {nd }}, 4^{\text {th }}, 8^{\text {th }}$, $10^{\text {th }}, 12^{\text {th }}, 14^{\text {th }}$, and $16^{\text {th }}$ post-wounding days. The statistical analysis was carried out using GraphPad prism software of version $5.0[15,16]$.

\section{RESULTS}

\section{Biocompatibility study}

Anti-inflammatory study

The anti-inflammatory study of PHB produced by A. chroococcum A3, $\mathrm{A} 4$, and B. megaterium was compared with commercial drug and was tabulated (Table 1). PHB from B. megaterium showed high activity then followed by A. chroococcum A3.

\section{MTT assay}

Regardless of the extensive use of PHB, there are no reports to confirm the cytotoxicity effects of PHB. The cytotoxicity of the PHB has been evaluated against HEK 293 cell lines at various concentrations ranging from 6.25 to $100 \mu \mathrm{g} / \mathrm{ml}$ (Fig. 1). The MTT assay was performed in HEK 293 cells. The concentration of MTT was found to be $20 \mu \mathrm{g} / \mathrm{ml}$. Fig. 1 showed the cytotoxicity activity of PHB with the $\mathrm{IC}_{50}$ value of $1.56 \mu \mathrm{g} / \mathrm{ml}$.

\section{PHB-plant and algal cast film preparation}

The formulations of PHB with various plant and algal blends were tabulated in Table 2 .

\section{Antimicrobial activities of biofilm with PHB against skin pathogens}

Turmeric rhizome with PHB showed better antimicrobial activities against skin pathogens followed by $P$. tetrastromatica and $A$. fragilissima whereas starch-based biofilms revealed very less significant toward the antimicrobial property. The maximum zone of inhibition was obtained by turmeric rhizome with PHB biofilm as $27.25 \pm 0.23 \mathrm{~mm}$ against skin

Table 1: Anti-inflammatory study of PHB

\begin{tabular}{ll}
\hline Extract & Inhibition (\%) \\
\hline PHB from A. chroococcum A3 & 45 \\
PHB from A. chroococcum A4 & 40 \\
PHB from B. megaterium & 48 \\
Commercial drug & 58 \\
\hline PHB: Polyhdrom
\end{tabular}

PHB: Polyhydroxybutyrate, A. chroococcum: Azotobacter chroococcum

Table 2: Plant and algal formulation with PHB

\begin{tabular}{ll}
\hline S. No & Samples \\
\hline 1 & PHB (F1) \\
2 & Sago starch 1\%+PHB (F2) \\
3 & Sago starch 2\%+PHB (F3) \\
4 & Amphiroa fragilissima+PHB (F4) \\
5 & Padina tetrastromatica+PHB (F5) \\
6 & Turmeric leaf 1\%+PHB (F6) \\
7 & Turmeric rhizome 1\%+PHB (F7) \\
8 & Standard \\
9 & Amphiroa fragilissima (F9) \\
10 & Padina tetrastromatica (F10) \\
\hline PHB: Polyhydroxybutyrate &
\end{tabular}

pathogens. P. tetrastromatica with PHB showed better antimicrobial activities against skin pathogens followed by turmeric leaf and P. tetrastromatica whereas starch-based biofilms revealed very less significant toward the antimicrobial property. The PHB showed less antimicrobial activity with $08.65 \pm 0.62 \mathrm{~mm}$ (Table 3 ).

Antioxidant capacity of various herbs impregnated with PHB Turmeric rhizome with PHB showed the highest percentage of inhibition of $76 \%$ followed by turmeric leaf. In contrast, starch-based PHB revealed less capturing of hydrogen free radicals. Similar trend was also observed in total antioxidant capacity using ammonium molybdate assay of estimating $\mathrm{IC}_{50}$ (Fig. 2). Highest $\mathrm{IC}_{50}$ indicated that less number of free radial capturing potential like chemical-based biofilm. Turmeric rhizome blended with partially purified PHB was exhibited very less value of $\mathrm{IC}_{50}$ around $75 \mu \mathrm{g} / \mathrm{ml}$ (Fig. 3).

\section{FRAP assay}

FRAP assay indicates that increase in absorbance leads to high reducing capacity of free radicals. A. fragilissima (F9) showed high percentage of inhibition followed by P. tetrastromatica (F10) and turmeric rhizome 1\%+PHB (F7) (Fig. 4).

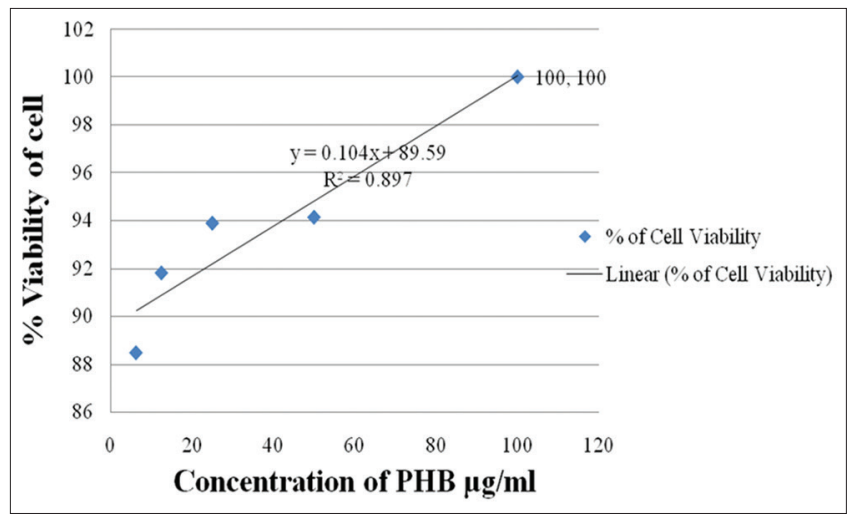

Fig. 1: (3-[4,5-Dimethylthiazol-2-yl]-2,5 diphenyl tetrazolium bromide) assay - cell viability of polyhydroxy butyrate

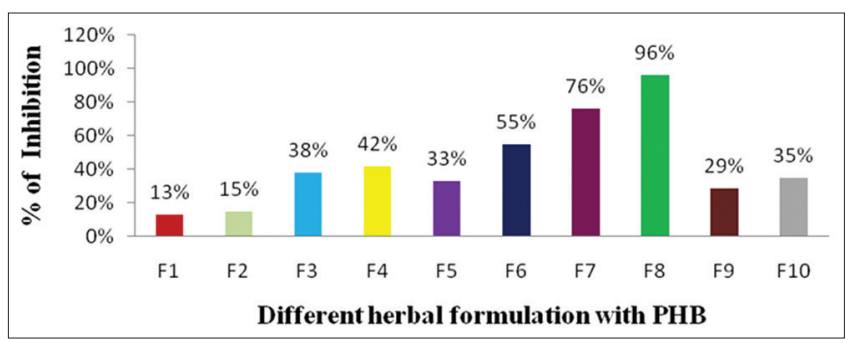

Fig. 2: 2,2-Diphenyl-2-picrylhydrazyl assay of hydrogen free radicals using herbs with polyhydroxybutyrate

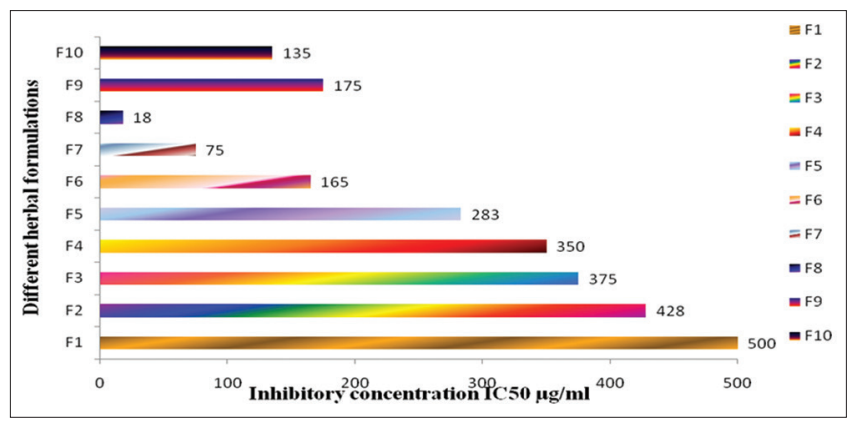

Fig. 3: Analysis of inhibitory concentration of polyhydroxybutyrate film 
Table 3: Antibacterial activities of herbal blended with biofilm against skin pathogens

\begin{tabular}{llllll}
\hline \multirow{2}{*}{ S. No } & \multicolumn{2}{l}{ Zone of inhibition (mm \pm SD) } & & & \\
\cline { 2 - 6 } & Formulation & Spp 1 & Spp 2 & Spp 3 & Spp 4 \\
\hline 1 & Control only PHB (F1) & $08.65 \pm 0.62$ & $10.82 \pm 0.33$ & $9.75 \pm 0.03$ & $10.23 \pm 0.43$ \\
2 & Sago starch 1\%+PHB (F2) & $15.32 \pm 0.73$ & $15.02 \pm 0.32$ & $14.95 \pm 0.63$ & $14.92 \pm 0.03$ \\
3 & Sago starch 2\%+PHB (F3) & $16.52 \pm 0.83$ & $16.68 \pm 0.28$ & $16.56 \pm 0.38$ & $16.60 \pm 0.85$ \\
4 & PHB+Seaweed 1 (F4) & $22.96 \pm 0.53$ & $23.06 \pm 0.53$ & $22.76 \pm 0.53$ & $21.76 \pm 0.53$ \\
5 & PHB+Seaweed 2 (F5) & $21.85 \pm 0.77$ & $21.73 \pm 0.87$ & $21.52 \pm 0.83$ & $21.85 \pm 0.23$ \\
6 & PHB+Turmeric leaf powder (F6) & $20.75 \pm 0.03$ & $23.45 \pm 0.37$ & $21.85 \pm 0.53$ & $20.42 \pm 0.83$ \\
7 & PHB+Turmeric rhizome powder (F7) & $26.25 \pm 0.33$ & $27.55 \pm 0.43$ & $26.95 \pm 0.63$ & $26.95 \pm 0.63$ \\
8 & Chloramphenicol (F8) & $23.06 \pm 0.62$ & $18.32 \pm 0.62$ & $17.12 \pm 0.62$ & $25.08 \pm 0.62$ \\
9 & Seaweed 1 (F9) & $22.26 \pm 0.62$ & $22.82 \pm 0.35$ & $22.16 \pm 0.53$ & $21.96 \pm 0.13$ \\
10 & Seaweed 2 (F10) & $21.76 \pm 0.63$ & $21.66 \pm 0.57$ & $22.11 \pm 0.33$ & $22.06 \pm 0.64$ \\
\hline
\end{tabular}

Spp 1: Klebsiella pneumonia, Spp. 2: Streptococcus pyogenes, Spp 3: Enterococcus sp., Spp 4: Corynebacterium spp. SD: Standard deviation

Hydrogen peroxide free radical scavenging assay

Maximum inhibition was observed at turmeric rhizome with $1 \%$ concentration followed by PHB with starch composites. Seaweed with polymer showed moderate inhibitory activity against hydroxyl ions. Turmeric rhizome and leaf exhibited significant activity compared to standard ascorbic acid (Table 4).

\section{Mechanical property of PHB-plant and algal cast film}

PHB with plants and algal blend films (Fig. 5) was subjected to TS, percentage of elongation and EM are the parameters that characterize the mechanical properties of films. The TS is the measurement of the maximum strength of a film to withstand applied tensile stress. The PHB (F1) is said to be $0.007 \pm 0.001 \mathrm{~N} / \mathrm{mm}^{2}$, whereas the highest TS found in F2, the average result was found in sample F6 and F7. Elongation at break is a measure of the film's stretchability before breakage. Percent elongation at break was calculated based on the length extended and original length of the films. The percentage elongation was found the maximum in F6 and F7. Young's modulus was estimated by the rigidity with higher values imply that the films are more rigid. EM was higher in F6 and F7 with $304 \pm 0.021$ and $325 \pm 0.027$, respectively (Table 5).

Wound healing activity of turmeric impregnated with $P H B$ on in vivo model

The wound healing activity of PHB with herbal films was studied on the incision wound model in rats (Fig. 6). The wound without treatment was used as a control. Percentage of wound contraction was measured on $2^{\text {td }}, 4^{\text {th }}, 6^{\text {th }}, 8^{\text {th }}, 10^{\text {th }}, 12^{\text {th }}, 14^{\text {th }}$ and $16^{\text {th }}$ days post-wounding days, at the $10^{\text {th }}$ day the healing percentage of control was $46 \%$, and PHB alone was $54 \%$. Turmeric leaf with PHB showed the highest activity with $84 \%$. At day 16, the control cured at $90 \%$ and turmeric leaf with PHB and turmeric rhizome with PHB showed $100 \%$ healing activity (Table 6). The result shows that PHB along with natural antiseptic gives promising results than crude PHB and control.

\section{DISCUSSION}

The PHB was subjected to anti-inflammatory and cytotoxicity assay, and the results revealed that it is biocompatible to use in medical applications. The $\mathrm{IC}_{50}$ value in MTT assay was $1.56 \mu \mathrm{g} / \mathrm{ml}$ showed that the livability of the cells was not affected. The percentage of inhibition was nearer to the commercial drug in anti-inflammatory activity, thus, can be used the alternative of the drugs which may have side effects. The PHB produced from A. chroococcum A3 was mixed with different herbal blends and subjected to antimicrobial and antioxidant activities. The TS, elongation break \%, and Young's modulus were examined. The evaluation of PHB and PHB/PP blendes degradation was carried out by Pachekoski et al. [17] showed that the TS of PHB and PHB/PP blends was 28.5 and $24.5 \mathrm{Mpa}$ with elongation break 2.5 and 1.5 with higher Young's modulus of 2045 and $1885 \mathrm{Mpa}$, respectively, degraded after 90 days in soil and reported with decrease in TS with which increases the degrading rate, the TS of PHB produced by cyanobacterium Chlorogloea
Table 4: Hydrogen Peroxide scavenging power assay

\begin{tabular}{lll}
\hline S. No & Samples & \% Inhibition \\
\hline 1 & Control (F1) & 08.55 \\
2 & PHB+Starch (F2) & 20.56 \\
3 & Sago starch 1\%+PHB (F3) & 14.56 \\
4 & Amphiroa fragilissima+PHB (F4) & 14.27 \\
5 & Padina tetrastromatica+PHB (F5) & 16.26 \\
6 & Turmeric leaf 1\%+PHB (F6) & 17.58 \\
7 & Turmeric rhizome 1\%+PHB (F7) & 21.2 \\
8 & Ascorbic acid & 13.53 \\
9 & Amphiroa fragilissima (F9) & 13.53 \\
10 & Padina tetrastromatica (F10) & 13.87 \\
\hline
\end{tabular}

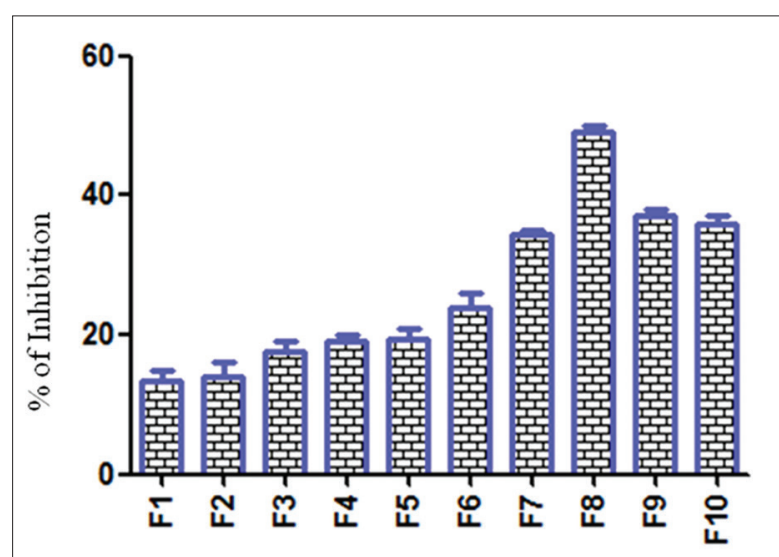

Frap Assay of plant and algal formulation with PHB

Fig. 4: Ferric reducing antioxidant power assay of the herbal formulation with polyhydroxybutyrate

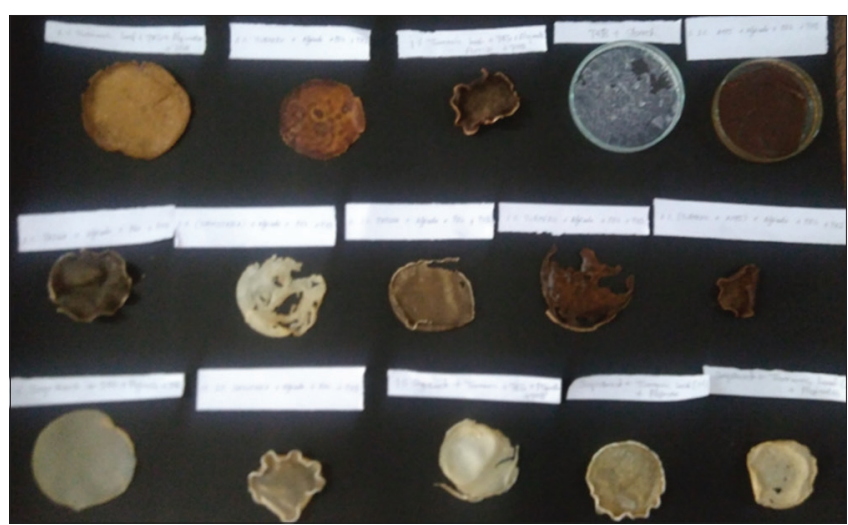

Fig. 5: Biofilm formulation using different herbal resources 
Table 5: Mechanical properties of different formulation with PHB

\begin{tabular}{llll}
\hline Particulars of cast film & Tensile strength $\left(\mathbf{N} / \mathbf{m m}^{\mathbf{2}} \pm\right.$ SD) & Film elongation $\mathbf{( \% \pm S D )}$ & Elastic module of the film (Mpa \pm SD) \\
\hline F1 - PHB & $0.007 \pm 0.001$ & $20.4 \pm 0.002$ & $289 \pm 0.056$ \\
F2 - Sago starch 1\%+PHB & $0.055 \pm 0.003$ & $13.84 \pm 0.001$ & $178 \pm 0.5$ \\
F3 - Sago starch 2\%+PHB & $0.035 \pm 0.003$ & $12.84 \pm 0.004$ & $176 \pm 0.53$ \\
F4 - Amphiroa fragilissima+PHB & $0.007 \pm 0.001$ & $20.4 \pm 0.002$ & $289 \pm 0.056$ \\
F5 - Padina tetrastromatica+PHB & $0.011 \pm 0.002$ & $20.6 \pm 0.004$ & $256 \pm 0.026$ \\
F6 - Turmeric leaf 1\%+PHB & $0.033 \pm 0.04$ & $25.1 \pm 0.006$ & $304 \pm 0.021$ \\
F7 - Turmeric rhizome 1\%+PHB & $0.039 \pm 0.04$ & $25.7 \pm 0.008$ & $325 \pm 0.027$ \\
F8 - Amphiroa fragilissima & $0.006 \pm 0.004$ & $19.8 \pm 0.002$ & $289 \pm 0.056$ \\
F9 - Padina tetrastromatica & $0.011 \pm 0.002$ & $20.6 \pm 0.004$ & $256 \pm 0.026$ \\
\hline
\end{tabular}

PHB: Polyhydroxybutyrate, SD: Standard deviation

Table 6: In vivo model of wound healing effect of various formulation with PHB

\begin{tabular}{|c|c|c|c|c|c|c|c|c|}
\hline \multirow[t]{3}{*}{ Particulars of cast film } & \multicolumn{8}{|c|}{ Degree of contraction $(\% \pm S D)$} \\
\hline & \multicolumn{8}{|c|}{ Number of days } \\
\hline & 2 & 4 & 6 & 8 & 10 & 12 & 14 & 16 \\
\hline Control & $8.33 \pm 2.2$ & $19 \pm 2.8$ & $28.6 \pm 0.9$ & $32 \pm 0.89$ & $46.2 \pm 0.006$ & $68 \pm 0.006$ & $79.5 \pm 0.07$ & $90.4 \pm 0.4$ \\
\hline PHB & $9.83 \pm 1.2$ & $18.6 \pm 0.06$ & $32.8 \pm 0.29$ & $43.5 \pm 0.04$ & $54 \pm 0.036$ & $71.9 \pm 0.22$ & $80.14 \pm 0.52$ & $91.3 \pm 0.56$ \\
\hline Turmeric leaf 1\%+PHB & $19 \pm 1.25$ & $29.7 \pm 0.28$ & $46.2 \pm 0.06$ & $68 \pm 0.26$ & $81.5 \pm 0.07$ & $89.4 \pm 0.34$ & $94.8 \pm 0.17$ & $98.9 \pm 0.01$ \\
\hline Turmeric rhizome $1 \%+\mathrm{PHB}$ & $20.5 \pm 0.59$ & $30.7 \pm 0.83$ & $49.82 \pm 0.29$ & $69.8 \pm 0.26$ & $83.7 \pm 0.08$ & $90.8 \pm 0.33$ & $96.5 \pm 0.47$ & $98.8 \pm 0.21$ \\
\hline Turmeric leaf $2 \%+$ PHB & $22.4 \pm 0.84$ & $37.3 \pm 0.39$ & $53.92 \pm 0.28$ & $76 \pm 0.33$ & $84.44 \pm 0.52$ & $92.46 \pm 0.49$ & $96.58 \pm 0.62$ & 100 \\
\hline Turmeric rhizome $2 \%+\mathrm{PHB}$ & $21 \pm 0.45$ & $34.7 \pm 0.58$ & $52.62 \pm 0.07$ & $72 \pm 0.09$ & $83.5 \pm 0.27$ & $91.2 \pm 0.14$ & $97.83 \pm 0.84$ & 100 \\
\hline
\end{tabular}

PHB: Polyhydroxybutyrate, SD: Standard deviation

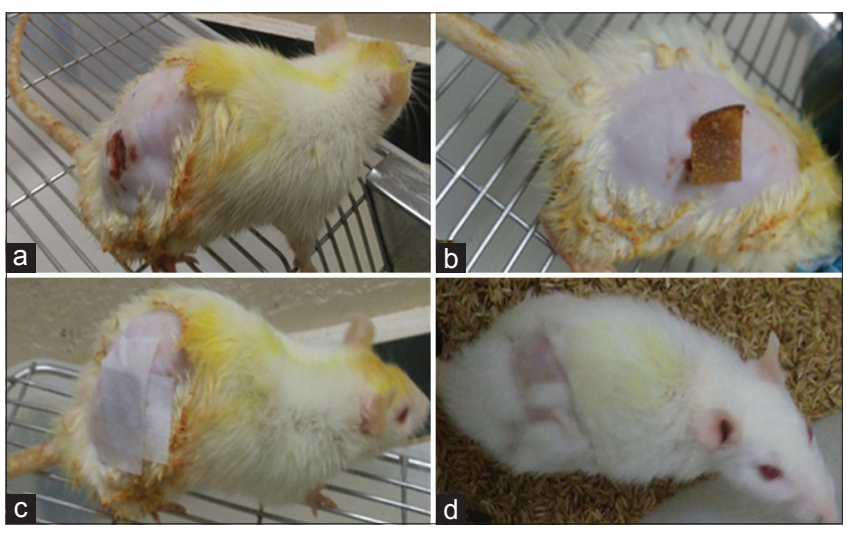

Fig. 6: Wound healing activity of turmeric blended with polyhydroxybutyrate (PHB) on rat model. (a) Incission of wound, (b) PHB with turmeric film, (c) sealed wound (a-c on day 1), and (d) healed wound on day 16

fritschii was 23Mpa with elongation break 5.5 and Young's modulus was 712Mpa [18]. The PHB produced in our study was entirely thin with F7 producing 0.39 Mpa TS and 25.7 elongation break and 325 Mpa Young's modulus which indicates that the PHB with lesser TS can act as a good biodegradable material.

Turmeric is a very good antiseptic since it was used as a traditional medicine from the ancient days to treat wounds. Since PHB is immunologically inert which will neither promotes or retards the wound healing activity. Turmeric rhizome with PHB showed good antimicrobial and antioxidant activity. PHB which is produced from $A$. chroococcum A3 was used as a carrier in the wound healing activity. PHB acts as a supportive material against wound healing activity, while PHB and turmeric will be a very good therapeutic agent against wound healing activity. The extracts of turmeric leaf and rhizome along with PHB will be a good combination in treating the wounds. Turmeric rhizome with PHB, the in vivo model was evaluated with Wistar rats. The evaluation reports that PHB is a very good supportive material in treating the wounds along with turmeric. Gayathri et al. [19] proved the antiseptic property of turmeric. Antibiotics and petrochemical derived combinational polymer covering the nucleus used in pearl culture could be detrimental for the environment. Tachyplesin, a marine peptide associated with bacterial exopolysaccharides act as a film agent and gave a same response as antibiotics in oyster mortality and nucleus rejection rates. Bacterial exopolysaccharides formed a strong coating on the nucleus and the tachyplesin incorporated into it showed, relatively a good antimicrobial property [20]. The conventional methods for wound healing were using the natural products having anti-inflammatory, antimicrobial, and antioxidant properties such as turmeric, neem, and honey the supportive biomaterials used so far were glucans, dextrans, chitosan, alginate, chondroitin, heparin, etc. [21].

In this study, apart from the regular biomaterials, PHB was used as a supportive material and in combination with plant and algal blends such as turmeric, sago starch, and seaweeds, but PHB alone plays no role in treating the wounds. However, turmeric rhizome with PHB yields very good result in treating the wounds, evaluated in the $10^{\text {th }}$ and $16^{\text {th }}$ days of the experiment. This type of trails was evaluated many times, but a combination of turmeric and PHB was not evaluated so for. A study by Kundu et al. [22] for the wound healing potential of turmeric rhizome in rabbits revealed that the contraction of wound area size at $14^{\text {th }}$ day was $4.47 \%$ which was much better than the control at $62.5 \%$. Another study with turmeric rhizome extract ointment revealed (RTO 6\%) that the wound contraction was $96.99 \%$ on the $16^{\text {th }}$ day and $100 \%$ on $18^{\text {th }}$ day [15]. In our study, the turmeric rhizome with PHB and turmeric leaf with PHB showed $100 \%$ wound contraction on the $16^{\text {th }}$ day, which was similar to the above studies. The antioxidant, antibacterial, and wound healing activity of several herbal plants were studied by Narendhirakannan et al. [23]. In their study, the $\mathrm{IC}_{50}$ of the antioxidant capacity of turmeric was $57.31 \mu \mathrm{g} / \mathrm{ml}$ and the standard ascorbic acid was $58.82 \mu \mathrm{g} / \mathrm{ml}$, which was closer to the standard. In our study, the $\mathrm{IC}_{50}$ of the standard and turmeric rhizome with PHB was 18 and 75 , respectively. The antioxidant capacity of turmeric rhizome with PHB was $76 \%$, and standard was $96 \%$ in our study. The antimicrobial activity of turmeric extracts was nearer to the standard drug streptomycin, while in our study the turmeric rhizome with PHB and turmeric leaf with PHB showed promising results against skin pathogens with a maximum zone of inhibition was observed in turmeric rhizome with PHB with $27.55 \pm 0.43$ against Streptococcus pyogenes, while the standard drug chloramphenicol showed $18.32 \pm 0.62$. The study by 
Narendhirakannan et al. [23] used only the extracts of various herbs, but in our study, the herbs are blended with PHB, and another study by Karri et al. [24] showed that curcumin incorporated in nanohybrid scaffold showed highest wound contraction of $98.1 \pm 3.4 \%$ at day 15 when compared to control with $44.6 \pm 6.3 \%$ at day 15 . Curcumin-loaded chitosan/gelatin sponge showed the good result of wound healing in rabbits with $95.41 \pm 3.62 \%$ at day 15 , which was higher than the control with $48.80 \pm 1.71 \%$ on the $15^{\text {th }}$ day [25]. Nanoformulated curcumin with gelatin was evaluated for anti-inflammatory and wound healing in cell lines and animal models [26]. In their study, curcumin was impregnated to nanofibrous mats (NM) with gelatin (Cc/Glt NM). The in vitro study of anti-inflammatory and wound healing was done in HS-27 cell lines. The in vitro study showed the significant anti-inflammatory effect of curcumin. The in vivo study was done in Sprague-Dawley rats, and the curcumin nanofiber mats (Cc/Glt NM) showed statistically significant wound healing at day 15 when compared to the control.

Turmeric proved to be effective in healing the wounds and PHB is an inert material, hence, which can be used as scaffold along with turmeric an antiseptic which will be a good source of treating wounds for fast recovery; PHB is a biopolymer which will not damage or enhance the cell growth since we have made a trail with in vitro cytotoxicity; and the result reveals that PHB will be a good source of treating many types of wounds. The anti-inflammatory and cytotoxicity assay revealed that PHB does not harm cell growth and proved to be a good candidate for scaffolding activity and can be used in a drug delivery system.

\section{CONCLUSION}

Different herbal formulation with PHB was prepared as a biofilm to elucidate the biological activities such as antimicrobial, antioxidant, anti-adherent, and wound healing property. Antioxidant capacity showed the highest inhibition in turmeric rhizome and leaf for $>50 \%$. The result indicated that turmeric rhizome coated with PHB showed highly significant in reducing wound activity rather than the other formulation in the rat model.

\section{ACKNOWLEDGMENT}

The authors are indebted to the Research and Development Centre of Bharathiar University, Coimbatore, Tamil Nadu, India, for the valuable suggestion and support.

\section{AUTHORS' CONTRIBUTION}

All the works were performed by Ram Narendran and manuscript was made ready by Ram Narendran, under the supervision of Dr. S.F. Maleeka Begum. Dr. S.F. Maleeka Begum contributed to manuscript preparation and MTT assay. Rubavathi S contributed to preparation of cast films.

\section{CONFLICTS OF INTEREST}

The authors declare that we do not have any conflicts of interest.

\section{REFERENCES}

1. Bonartsev AP, Myshkina VL, Nikolaeva DA, Furina EK, Makhina TA, Livshits VA, et al. Biosynthesis, biodegradation, and application of poly (3- hydroxybutyrate) and its copolymers - Natural polyesters produced by diazotrophic bacteria. Commun Curr Res Edu Topic Trends Appl Microbiol 2007;2007:295-307

2. Pfeiffer D, Jendrossek D. PhaM is the physiological activator of poly (3- Hydroxybutyrate) (PHB) synthase (PhaC1) in Ralstonia eutropha. Appl Environ Microbiol 2014:80:555-63.

3. Chen GQ, Wu Q. The application of polyhydroxyalkanoates as tissue engineering materials. Biomaterials 2005;26:6565-78

4. Xavier JR, Babusha ST, George J, Ramana KV. Material properties and antimicrobial activity of polyhydroxybutyrate (PHB) films incorporated with vanillin. Appl Biochem Biotechnol 2015;176:1498-510.

5. Babu PK, Maruthi Y, Pratap S, Sudhakar K, Sadiku R, Prabhakar MN, et al. Development and characterization of polycaprolactone (PCL)/ poly ((R)-3-Hydroxybutyric acid) (PHB) blend microspheres for tamoxifen drug release studies. Int J Pharm Pharm Sci 2015;7:95-100.

6. Gonta S, Savenkova L, Krallish I, Kirilova E. Antimicrobial activity of PHB based polymeric compositions. Environ Eng Manag J 2012;11:S92

7. Kim MR. Antimicrobial activity of PHB/chitosan films and quality of white bread packaged with the films. Korean J Hum Ecol 2005; 14:321-30

8. Shishatskaya EI, Volova TG. A comparative investigation of biodegradable polyhydroxyalkanoate films as matrices for in vitro cell cultures. J Mat Sci 2004;15:915-23.

9. Wei X, Hu YJ, Xie WP, Lin RL, Chen GQ. Influence of poly (3-hydroxybutyrate-co-4-hydroxybutyrateco-3-hydroxyhexanoate) on growth and osteogenic differentiation of human bone marrow-derived mesenchymal stem cells. J Biomed Mat Res A 2009;90:894-905.

10. Sevastianov VI, Perova NV, Shishatskaya EI, Kalacheva GS, Volova TG. Production of purified polyhydroxyalkanoates (PHAs) for applications in contact with blood. J Biomat Sci Polymer 2003;14:1029-42.

11. Brigham CJ, Sinskey AJ. Applications of polyhydroxyalkanoates in the medical industry. Int J Biotechnol Wellness Indus 2012;1:53-60.

12. Mosmann T. Rapid colorimetric assay for cellular growth and survival: Application to proliferation and cytotoxicity assays. J Immunol Methods 1983;65:55-63.

13. Kirby WM, Bauer AW, Sherris JC, Turck M. Antibiotic susceptibility testing by a standardized single disk method. Tech Bullet Regis Med Technol 1966;36:49-52.

14. Mahendran G, Manoj M, Prasad KJ, Bai VN. Antioxidants, antiproliferative, anti-inflammatory, anti-diabetic and anti-microbial effects of isolated compounds from Swertia corymbosa (Grieb.) Wight ex C.B. Clark - An In vitro approach. Food Sci and Human Wellness 2015:4:169-79.

15. Farahpour MR, Emami P, Ghayour SJ. In vitro antioxidant properties and wound healing activity of hydroethanolic turmeric rhizome extract (ZINGIBERACEAE). Int J Pharm Pharm Sci 2014;6:474-8.

16. Rajeshwaran T, Sumathy R, Kumuthakalavalli R. Wound healing effect of king Alferd's mushroom (Daldinia concentrica) used by tribes of Sirumalai Hills, Tamil Nadu, India. Int J Pharm Pharm Sci 2017;9:161-4

17. Pachekoski WM, Agnelli JAM, Belem LP. Thermal, mechanical and morphological properties of poly (Hydroxybutyrate) and polypropylene blends after processing. Mat Res 2009;12:159-64

18. Monshupanee T, Nimdach P, Incharoensakdi A. Two-stage (photoautotrophy and heterotrophy) cultivation enables efficient production of bioplastic poly-3-hydroxybutyrate in auto-sedimenting cyanobacterium. Sci Rep 2016;6:37121.

19. Gayathri A, Sekar DS, Sakthi R. Wound healing activity of Curcuma longa with Oleum olivae. J Aca Ind Res 2015;3:479-80.

20. Simon-Colin C, Gueguen Y, Bachere E, Kouzayha A, Saulnier D, Gayet $\mathrm{N}$, et al. Use of natural antimicrobial peptides and bacterial biopolymers for cultured pearl production. Mar Drugs 2015;13:3732-44.

21. Mogoşanu GD, Grumezescu AM. Natural and synthetic polymers for wounds and burns dressing. Int J Pharm 2014;463:127-36.

22. Kundu S, Biswas TK, Das P, Kumar S, De DK. Turmeric (Curcuma longa) rhizome paste and honey show similar wound healing potential: A preclinical study in rabbits. Int J Low Extrem Wounds 2005;4:205-13.

23. Narendhirakannan RT, Nirmala JG, Caroline A, Lincy S, Saj M, Durai D. Evaluation of antibacterial, antioxidant and wound healing properties of seven traditional medicinal plants from India in experimental animals. Asian Pac J Trop Bio 2012;2012:S1245-53.

24. Karri VV, Kuppusamy G, Talluri SV, Mannemala SS, Kollipara R, Wadhwani $\mathrm{AD}$, et al. Curcumin loaded chitosan nanoparticles impregnated into collagen-alginate scaffolds for diabetic wound healing. Int J Biol Macromol 2016;93:1519-29.

25. Nguyen VC, Nguyen VB, Hsieh MF. Curcumin-loaded chitosan/gelatin composite sponge for wound healing application. Int J Poly Sci 2013. Doi.org/10.1155/2013/106570.

26. Dai X, Liu J, Zheng H, Wichmann J, Hopfner U, Sudhop S, et al. Nano-formulated curcumin accelerates acute wound healing through Dkk-1-mediated fibroblast mobilization and MCP-1-mediated antiinflammation. NPG Asia Mat 2017;9:1-14. 